Bart Stellinga*†

\title{
The open-endedness of macroprudential policy. Endogenous risks as an obstacle to countercyclical financial regulation
}

\begin{abstract}
After the global financial crisis of 2007-9, policymakers hailed macroprudential policy as the solution to financial markets' boom-bust patterns. Financial regulations would have to operate countercyclically, increasing in stringency during a boom while becoming lenient in a bust. Simultaneously, the procyclical effects of pre-crisis rules would have to be eliminated. Actual reforms, however, do not live up to these high hopes. In addition to the countercyclical policy framework's limited scope and ambition, its open-endedness is particularly striking. As policymakers have not specified when supervisors should (de)activate what instruments and how firms should measure risk, there is an inbuilt indeterminacy at macroprudential policy's core. I argue that obstacles inherent to the nature of systemic risk are key to understanding this policy outcome. As the financial system is reflexive, adaptive, and complex, there are hard limits to supervisors' ability to "read" the financial cycle. Furthermore, as macroprudential policy itself becomes "part of financial markets," countercyclical interventions may have systemically significant unintended consequences. This article empirically shows how policymakers at the global and EU level, confronted with these measurement and mitigation problems, ultimately opted for a limited and open-ended policy framework.
\end{abstract}

Keywords: macroprudential, systemic risk, financial crisis, financial regulation, countercyclical

doi:10.1017/bap.2019.14

\footnotetext{
*Corresponding author: Bart Stellinga, Department of Political Science, University of Amsterdam, Nieuwe Achtergracht 166, 1018 WV, Amsterdam, The Netherlands; Email: b.j.p.stellinga@uva.nl

$\dagger$ This research was supported by the Horizon 2020 program of the European Union, through the ENLIGHTEN project (649456). An earlier version of this article was presented at workshops at the University of Amsterdam, the Paris Institute for Advanced Study (IAS), and the Sheffield Political Economy Research Institute (SPERI) of the University of Sheffield. I would like to thank all participants for their useful comments and suggestions, in particular Andrew Baker, Matthias Thiemann, Samuel McPhilemy, Nathan Coombs, Daniel Mügge and Jonathan Zeitlin. I also want to thank my interviewees for their willingness to help me with this research.
}

(C) V.K. Aggarwal and Cambridge University Press 2019. This is an Open Access article, distributed under the terms of the Creative Commons Attribution licence (http://creativecommons.org/licenses/by/4.0/), which permits unrestricted re-use, distribution, and reproduction in any medium, provided the original work is properly cited. 


\section{Introduction}

The global financial crisis of 2007-9 challenged the pre-crisis orthodoxy of self-stabilizing markets. So-called "macroprudential ideas," emphasizing financial markets' inherent destabilizing tendencies, quickly gained popularity. Key policymaking institutions, such as the Bank for International Settlements (BIS), the Financial Stability Board (FSB), and the International Monetary Fund (IMF), argued that financial markets are prone to procyclicality: the amplification of system-wide risk by interactions within the financial system, as well as between this system and the real economy. ${ }^{1}$ Policymakers agreed that a countercyclical regulatory approach was necessary to mitigate markets' boom-bust nature. Under the flag of macroprudential policy reforms, they set out to redesign regulatory frameworks so that rules would become more stringent when systemic risks build up and more lenient if risks materialized. ${ }^{2}$ Rules on firms' risk management practices would also have to be reformed to ensure that they would not contribute to procyclicality.

International political economy (IPE)-scholars have presented macroprudential ideas' quick ascendance as tentative evidence that a fundamental policy shift was underway, even if it would take some time to fully materialize. ${ }^{3}$ The reforms actually implemented, however, are a far cry from post-crisis hopes. ${ }^{4}$ The countercyclical policy framework's ambition and scope are limited, but what is particularly striking is its open-endedness. While policymakers have included several countercyclical tools in regulation, it is unclear when supervisors should do what. Instead of developing clear strategies to systemic risk measurement, policymakers have produced longlists of potentially relevant indicators. They have also not specified how supervisors should respond to the buildup and materialization of systemic risks, by and large leaving this up to the relevant authorities. Similarly, policymakers have struggled to mitigate the pre-crisis frameworks' procyclical elements. Rather than curbing destabilizing practices by becoming much more prescriptive on firms' risk models, policymakers have settled for limited reforms where firms retain a significant amount of discretion. This open-endedness is no marginal issue: as policymakers have not specified when to (de)activate what instruments and how firms should measure risk, there is an inbuilt indeterminacy at macroprudential policy's core.

\footnotetext{
1 Borio (2009).

2 BIS (2008); FSB et al. (2011).

3 Baker (2013a; 2013b); Mackintosh (2014); Lothian (2012).

4 Baker (2018).
} 
This outcome is hard to square with initial expectations of a fundamental paradigm shift. Many IPE-explanations for limited reforms take the "macroprudential promise" as a given, focusing primarily on the policy processes leading to regulatory reforms. Despite their differences, these explanations implicitly assume that an effective policy solution to the procyclicality problem was readily available: policymakers could have designed models to confidently measure systemic risks and tools to mitigate them. Explanations for lack of its implementation include ideological resilience, institutional inertia, bank lobbying, and international coordination problems. $^{5}$

I argue that to understand the framework's open-endedness, we have to reassess this assumption. We should focus not only on policy processes, but also on the nature of the problem that the "macroprudential promise" should address: the endogeneity of systemic risk. ${ }^{6}$ This endogeneity introduces two fundamental problems for countercyclical policy. First, it hampers policymakers in designing strategies to measure the buildup of systemic risks. Financial markets' selfreferential, dynamic and complex nature implies that they are prone to irregular boom-bust patterns. While supervisors can identify particular factors that historically accounted for future trouble, they face inherent uncertainty as to its precise origin, timing, and manifestation. Identifying systemic risks will, thus, inevitably maintain a high degree of uncertainty and guesswork, leading policymakers to embrace an open-ended approach.

Second, the endogeneity of systemic risk hampers policymakers in designing strategies to mitigate systemic risks. While any particular policy intervention has potential unintended consequences, countercyclical actions are special, in that they are aimed at the system as a whole. As such, an ill-timed, forceful countercyclical intervention might trigger the stress that supervisors aim to prevent. A rule-based framework is better in this regard, but this approach could become self-defeating as market participants modify their behavior in response. In the absence of a clear solution, policymakers have effectively delegated the problem to supervisors. The mitigation problem includes attempts to limit the procyclical effects of banks' risk management strategies. The obvious solutionprescribing particular risk models-could actually stimulate herd behavior, thereby making things worse. Still, leaving it up to the firms themselves allows for opportunistic behavior. Policymakers, thus, see no way out but to opt for half-baked, open-ended solutions.

5 Konings (2016), Underhill (2015), and Baker (2018) emphasize ideological factors. Lombardi and Moschella (2017) stress institutional inertia. Helleiner (2014) specifically points at bank lobbying. Thiemann et al. (2018) highlight international coordination difficulties.

6 Minsky (2008 [1986]); Daníelsson et al. (2001); Soros (2008). 
I illustrate this argument by focusing on countercyclical policies developed in global forums (specifically, the BIS) and at the European level. I discuss the problems that policymakers encountered when designing systemic risk measurement and mitigation strategies. Drawing on policy documents and confidential interviews with senior policymakers and banking sector representatives ${ }^{7}$, the empirics show that policymakers' identification of these measurement and mitigation problems induced caution and open-ended rules, rather than sweeping reforms.

\section{The open-endedness of macroprudential policy}

The procyclicality problem was at the core of the macroprudential policy debate. ${ }^{8}$ Policymakers argued for countercyclical elements in a broad set of rules. This would ensure that rules would become more stringent as systemic risks build up, while becoming more lenient when risks recede or materialize. ${ }^{9}$ Policymakers also saw merit in time-invariant backstops: limits on firms' room for maneuvering that do not vary over the cycle. Examples are maximum loanto-value ratios or a leverage ratio. Yet compared with time-varying instruments, policymakers generally regarded such backstops as second-best solutions: fixed instruments cannot effectively constrain systemic risk under all circumstances, and they can have procyclical effects in a downturn. ${ }^{10}$ Critics of the pre-crisis regulatory approach also argued that financial firms' risk assessment practices, such as reliance on Value-at-Risk models and fair-value accounting, had put procyclicality into overdrive. ${ }^{11}$ These practices would, thus, have to be reregulated, so as to ensure that they would no longer contribute to procyclicality. ${ }^{12}$

\section{The reforms actually implemented}

IPE-scholarship has identified several drivers for macroprudential reforms, including the failure of the pre-crisis regulatory philosophy, the availability of a promising alternative, and policymakers' aspiration to reassert themselves vis-à-vis the

7 These interviews took place in Amsterdam, Basel, Frankfurt, and Brussels. To ensure confidentiality, I do not disclose the organizations' names.

8 The other main issue was the problem of structural systemic risks, resulting from firms' common exposures or from them being systemically important.

9 FSA (2009b); FSF (2009); Committee on the Global Financial System [CGFS] (2012); Haldane (2012).

10 BIS (2008); Domanski and Ng (2011); Claessens et al. (2014).

11 Warwick Commission (2009).

12 BIS (2008); FSF-BCBS (2009); FSF-CGFS (2009); FSF (2009). 
private sector. ${ }^{13}$ Analysts acknowledged that a full transformation would take some time, with policymakers needing to gain practical experience with the new approach. Still, a future transformation seemed likely, involving "incremental steps in the direction of an activist functioning macroprudential regulatory regime." 14

Post-crisis calls for macroprudential reforms have certainly led to much action at the global, European, and national levels. The EU, for example, set up the European Systemic Risk Board (ESRB) to monitor systemic risks and issue warnings and recommendations to national authorities. The European Central Bank (ECB) also has some macroprudential competences for Euro-area member states' banking sectors. EU member states have assigned macroprudential tasks to specific authorities, although the formal remit and the composition of different authorities vary. ${ }^{15}$ The EU included explicit macroprudential instruments in legislation (most notably in the Capital Requirements Directive [CRD] IV and Capital Requirements Regulation [CRR]), and member states introduced additional instruments at the national level. Authorities undertook extensive research efforts and data gathering exercises to improve the monitoring and mitigation of systemic risks. ${ }^{16}$ Finally, policymakers modified microprudential frameworks, such as risk-sensitive capital requirements, to limit their procyclical effects.

While macroprudential policy is now an established part of financial governance, its significance remains disputed. Zooming in on the procyclicality problem, the scope of countercyclical elements is limited. Most macroprudential instruments-for example, the leverage ratio and the capital conservation bufferare a-cyclical backstops, meaning that supervisors do not vary the rules' stringency over time. While such instruments can certainly limit unsustainable credit growth, ${ }^{17}$ they are a long way from post-crisis hopes for countercyclical rules. ${ }^{18}$ In many policy domains-liquidity rules, margin and haircuts requirements, accounting rules, credit extension-there are no formal countercyclical instruments as of yet. ${ }^{19}$

Countercyclical elements are, by and large, confined to bank capital requirements. But also here, their significance seems limited. The most important policy

13 Baker (2013a; 2013b); Helleiner (2014).

14 Baker (2013a), 430.

$15 \operatorname{ESRB}(2016 a)$.

16 ESCB Heads of Research (2014).

17 As leverage is procyclical, a time-invariant leverage ratio can certainly mitigate procyclicality; cf. Adrian and Shin (2009). Many observers argue that the rules actually implemented are too lenient; cf. Admati and Hellwig (2013); Hellwig (2014); Admati (2016).

18 Domanski and Ng (2011).

$19 \operatorname{ESRB}$ (2014a); ECB (2015b). 
tool is the countercyclical capital buffer (CCB) - adopted from the new Basel III accord-that national macroprudential authorities can activate in case systemic risks are building up. ${ }^{20}$ EU law also allows national authorities to increase sectoral risk-weights for banks' real estate exposures if deemed necessary to mitigate systemic risk. ${ }^{21}$ The so-called "flexibility package" (Article 458 of the CRR) allows member states to temporarily increase the stringency of some regulatory tools. This article is, however, consciously designed to be a last resort for national authorities, only to be used when all other options prove insufficient. ${ }^{22}$ Far from occupying a central place, countercyclical elements have been consigned a peripheral role in the broader policy framework.

Perhaps even more remarkable is the policy framework's open-endedness. Policymakers have not converged on ways to measure systemic risks and strategies to mitigate them. While the CCB-rules refer to a specific systemic risk indicatorthe credit-to-GDP gap, measuring the deviation from the trend of the ratio of "credit to the private sector" to "a country's GDP" - supervisors are not required to use it. ${ }^{23}$ Instead, authorities have formulated longlists of potentially relevant variables to help them decide when to activate countercyclical elements. ${ }^{24}$ Although this surely improves systemic risk analysis, supervisors and market participants are in the dark about under what circumstances tools should be activated or released. There is also much uncertainty about how supervisors should respond to the buildup and materialization of systemic risk. As the rules leave this up to the supervisors to decide, ${ }^{25}$ policymakers seem to have displaced rather than solved the problem. This strikes at the heart of macroprudential policymaking: as supervisors do not really know when and how to (de)activate instruments, there is an inbuilt indeterminacy at the core of countercyclical policies.

This open-endedness also characterizes reforms of firms' valuation and risk management routines. ${ }^{26}$ Policymakers have refrained from prescribing these routines, settling instead for an adaptation of pre-crisis approaches rather than a sweeping overhaul. ${ }^{27}$ Supervisors check whether banks' risk models have sufficiently long time horizons and "pessimistic" loss scenarios. ${ }^{28}$ Similarly, the new EU accounting standard for financial instruments (IFRS 9) allows forward-looking

$20 \operatorname{ESRB}(2014 b)$.

21 See EC (2016a), 7.

22 EC (2016a).

$23 \operatorname{ESRB}(2014 b)$.

24 See, for example, Financial Policy Committee (2016).

25 CGFS (2016).

26 Lockwood (2015).

27 Stellinga and Mügge (2017).

28 EBA (2015). 
loan-loss provisioning. ${ }^{29}$ But these requirements still give banks a lot of discretion. As such, risk management routines may still have significant procyclical effects.

\section{IPE-explanations for limited reforms}

Within IPE-scholarship there is now "a growing sense that the "macroprudential turn' [...] is increasingly constrained and minimal in its ambition." 30 Why have central banks and banking regulators-generally regarded as the leading actors in macroprudential policy reforms ${ }^{31}$-stopped short of a drastic overhaul? At the risk of oversimplification, IPE-accounts can be classified by two types of explanations. ${ }^{32}$ The first emphasizes obstacles external to the change-oriented actors, for example, private sector opposition or institutional path-dependencies. ${ }^{33}$ Key actors were willing to implement sweeping reforms, but failed to overcome unsurmountable opposition, so the argument goes. Explanations within this strand, thus, focus on the political struggles in the implementation of reforms, while downplaying potential difficulties in translating macroprudential ideas in workable policies.

A second strand emphasizes disagreements within the macroprudential policy community as a key factor hindering reforms. ${ }^{34}$ It stresses that macroprudential ideas were compatible with multiple policy strategies, ranging from the minimalist (resiliency) strategy to more ambitious, "anti-cyclical" variants. ${ }^{35}$ This redirects our attention to macroprudential experts' preferences and ideas as they set out to design reforms. IPE-scholars highlight several reasons for limited reforms, including regulators' preference for evidence-based policies, ${ }^{36}$ their reluctance to get involved in issues with obvious distributional consequences, ${ }^{37}$ and macroprudential ideas' compatibility with pre-crisis regulatory strategies. ${ }^{38}$ While these explanations rightly stress the importance of countercyclical reforms' technicalities, they pay rather limited attention to the possible dilemmas that regulators

29 ECB (2015a).

30 Baker (2018), 294-5. See also Helleiner (2014); Underhill (2015); Konings (2016); Lombardi and Moschella (2017); Thiemann et al. (2018); Thiemann (2018).

31 Baker (2013b); McPhilemy 2016; Thiemann (2018).

32 This broad classification is for analytical purposes only: explanations falling within similar strands may differ substantially on many other aspects.

33 Baker (2013a; 2013b); Underhill (2015); Goodhart (2015).

34 Helleiner (2014); Thiemann (2018); Baker (2018).

35 Cf. Thiemann (2018).

36 Thiemann (2018).

37 Baker (2018).

38 Helleiner (2014); Konings (2016). 
would encounter if they were to implement more ambitious countercyclical policies.

These two strands share the implicit assumption that an effective policy framework to eliminate the procyclicality problem was readily available, but differ on why it was not implemented: the first stresses policymakers' inability to do so, the second their unwillingness. I argue that to understand why the leading actors of macroprudential policy reforms - central bankers and financial regulators-have ultimately embraced a rather unspecified policy framework, we must reassess this assumption. Macroprudential ideas did not, by themselves, provide fool-proof regulatory solutions to the identified problems. It is one thing to understand the problem and identify the need for countercyclical policies, and quite another one to actually design them. Policymakers had to develop ways of identifying the buildup of systemic risks. They also had to design strategies to mitigate these risks. But precisely on those issues, policymakers encounter fundamental problems.

\section{The measurement and mitigation problems}

These regulatory problems paradoxically find their roots in one of the macroprudential philosophy's core ideas: the endogeneity of systemic risk. ${ }^{39}$ Systemic risks are endogenous for three reasons. First, the financial system is reflexive: market participants' beliefs about inherently uncertain future outcomes in the aggregate shape these outcomes. Financial markets have no firm anchors-the ofteninvoked fundamental values in the real economy-outside of market participants' assessments. ${ }^{40}$ Second, the financial system is adaptive. It is constantly changing as a result of new products, institutions, technologies, actors, ideas, and regulations; implying yesterday's system is quite different from today's or tomorrow's system. While systemic risks are inherent to financial markets, their precise manifestation will, thus, change over time. ${ }^{41}$ Finally, the system is complex, meaning financial markets are susceptible to unpredictable and non-linear transitions. Transgressing particular thresholds may trigger feedback loops that makes the system spiral away from a seemingly stable "equilibrium" and into the abyss. ${ }^{42}$

39 The idea that systemic risks are endogenous to financial markets gained popularity in the early 2000s. Pioneering work on this issue was done at the BIS-Crockett (2000); Borio (2003); White (2004)—and the London School of Economics-Daníelsson et al. (2001); Daníelsson and Shin (2003).

40 Bronk (2013); Soros (2008).

41 Agur and Sharma (2013).

42 May et al. (2008). 
In sum, with no solid anchors, financial markets are characterized by irregular boom-bust patterns. ${ }^{43}$

Yet these insights pose two fundamental problems for countercyclical policy. First, it obstructs a straightforward measurement of systemic risk. Systemic risk indicators based on market data are of only limited use. Given that the buildup of risk is the consequence of collective optimism, market data will, by definition, fail as an early warning device. Indicators based on historical trends are better in this regard, but these still suffer from the endogeneity problem. Reflexivity implies that changes in market participants' expectations and actions may quickly transform seemingly benign conditions into a collapse in market liquidity and asset values. And although instability is inherent to financial markets, the precise origin, manifestation, and severity changes over time. Market distress often results from innovation, which, by definition, makes historical comparisons difficult. $^{44}$ There are, thus, inherent measurement problems that severely hamper the calibration of countercyclical instruments.

This suggests that a discretionary approach to countercyclical policy is inevitable. Yet even when supervisors take into account many different systemic risk indicators, the measurement problems do not disappear. Supervisors cannot "step out" of the reflexivity dynamics and assess risk from an "external" point of view. Instead, they have to determine the buildup of fragility from within the system, and there is no obvious place to look. While supervisors can identify particular factors that generally signal the buildup of risk, there will always be a significant degree of uncertainty and guesswork. Supervisors will have to fly by sight, rather than on autopilot.

Second, the endogeneity problem obstructs a straightforward mitigation of systemic risk. Macroprudential policies become part of financial markets: market participants pay attention to these rules and second guess supervisors' interventions. While this "policy endogeneity" applies to all policies, macroprudential policy is special in that it concerns systemic interventions, which also implies significant unintended consequences. A rule-based approach is limited due to measurement limitations and the risk of regulatory arbitrage. But the unpredictability that discretionary policies introduce can have undesirable side effects: an ill-timed, forceful intervention-whether it is through tightening or loosening requirements-can be interpreted as a signal that trouble is underway, triggering the stress that supervisors want to avoid. Moreover, especially during market distress, there is very little that supervisors can do, and an overly ambitious countercyclical policy may add to the problems. If macroprudential leniency takes

43 Minsky (2008 [1986]).

44 Bronk (2013). 
precedence over microprudential stringency, individual firms may go bankrupt, which adds to the panic. If leniency allows firms to hide losses, this postpones but also prolongs financial problems. Unfortunately, there is no straightforward approach to countercyclical policy.

This mitigation problem is not confined to top-down countercyclical policy, but it also blocks a straightforward solution to firms' risk management routines' procyclical effects. In a reflexive system, widespread use of particular risk models can ensure that these models shape rather than measure reality. In the words of Donald MacKenzie, models are an "engine, not a camera." 45 Yet this also introduces a regulatory problem. Even if reliance on privately designed risk models contributed to procyclical tendencies, the obvious alternative-regulator-designed approaches-risks contributing to herd behavior. To the extent that pre-crisis rules stimulated homogeneous market responses, regulatory flexibility in the domain of risk models may facilitate opportunistic behavior, while still allowing private sector herding. Neither a laissez-faire, nor a hands-on, approach promises to eliminate the destabilizing effects of firms' valuation approaches.

Adding to the problem, each risk approach comes with serious downsides. The procyclicality debate is whether firms should make point-in-time (PIT) or throughthe-cycle (TTC) risk assessments. PIT models assess an exposure's riskiness based on current conditions; if market conditions change, assessments should be revised. Critics blame such cycle-sensitive outputs for inducing procyclicality and present TTC models as more desirable alternatives. ${ }^{46}$ These attempt to filter out cyclical effects through the use of longer time-horizons, implying risk assessments should not be revised when overall market conditions change. But while TTC models provide more stability, they may downplay market trends too much. It encourages firms to ignore mounting problems until it is too late, meaning they are unprepared for what hits them. Similarly, in the downturn it might induce them to understate problems. While this might mitigate shortterm stress, it could merely make future problems worse. This creates fundamental policy problems: both PIT models and TTC models can have severe unintended consequences, and regulatory prescriptiveness might worsen their destabilizing potential. $^{47}$

The empirical body of this article details the problems policymakers encountered in the process of designing a countercyclical policy framework. I do so by discussing the two main issues that policymakers had to address: (1) designing strategies to measure systemic risks and (2) to mitigate them (addressed in sections

45 MacKenzie (2006), 259. MacKenzie labels this effect as "performativity."

46 Warwick Commission (2009).

47 Mügge and Stellinga (2015). 
3 and 4, respectively). My goal is not to present exhaustive descriptions of political processes leading up to particular outcomes. Instead, both sections show that even armed with new ideas, policymakers struggled to design coherent countercyclical strategies, ultimately opting for an open-ended approach.

\section{The measurement problem in practice}

\section{Designing an early warning system}

The financial crisis exposed major flaws in supervisors' ability to identify systemic risks. In the EU, the influential De Larosière-report called for an "early warning system" that would identify “'danger zones' for key variables, the entry of which would be to trigger the presumption of the need for intervention [...]." 48 The European Systemic Risk Board (ESRB) was subsequently tasked with "developing a common set of quantitative and qualitative indicators (risk dashboard) to identify and measure systemic risk." ${ }^{49}$ Yet the risk dashboards that the ESRB has published since all emphasize an important disclaimer on the first page: "The risk dashboard is a set of quantitative indicators and not an early-warning system. Users may not rely on the indicators as a basis for any mechanical form of inference." 50 What explains this cautious approach?

The risk dashboard mostly relies on market-based indicators (such as volatilities and credit risk spreads) and balance-sheet data (such as measures of banks' capitalization and profits). Yet market reflexivity limits their usefulness as early warning indicators, as such indicators are reflections of current market sentiment. BIS-researchers link this problem to the so-called "paradox of instability": "the system looks strongest precisely when it is most vulnerable. Credit growth and asset prices are unusually strong, leverage measured at market prices artificially low, and risk premia and volatilities unusually low precisely when risk is highest." ${ }^{51}$ BIS expert William White stressed early on that "if the underlying problem is that everything is endogenous, one can move very quickly from states where 'all looks well' to a much more serious set of circumstances," arguing that this implies "that we must not rely overly on 'market-based' indicators to identify looming problems, if it is the market itself which is being overly

48 High-Level Working Group on Financial Supervision in the EU (2009), 65.

49 European Parliament and European Council (2010), article 3(g).

50 For example: ESRB (2018), 1.

51 Borio (2011), 17. 
optimistic." 52 Indeed, the record shows that market-based indicators are very procyclical: they signal low risk in good times, and vice versa. This makes them primarily useful as signals of current market distress (thermometers) rather than as early warning indicators (barometers). ${ }^{53}$

Identifying the risk dashboard's limitations, an external evaluation report published in 2013 called for improving the ESRB's early warning system. It proposed the quarterly publication of a "heat map" that would contain "the ESRB's view on key short- and medium-term systemic risks." 54 The ESRB would thereby fulfil its legal obligation to develop a "colour-coded system corresponding to situations of different risk levels," in order to "enhance the awareness of risks in the economy of the Union and to prioritise such risks." 55 In response, the ESRB started work on designing heat maps that would "provide signals of a potential buildup of vulnerabilities that may require further analysis and potential changes in policy stances, when country-based indicators breach pre-defined thresholds." ${ }^{56}$ Yet two years later the ESRB abandoned this route, mentioning that these heat maps would be for internal use only. ${ }^{57}$ As such, it failed to live up to the Regulation's call for enhancing public awareness of systemic risks.

Also here, the limits to systemic risk measurement proved a key obstacle. The ESRB's original plan was to have heat maps signaling problems based on historical crises experiences, relying on the same indicators as the risk dashboard, but looking at deviations from long-term trends or averages. ${ }^{58}$ But such indicators come with problems of their own. Market distress often results from a period of rapid financial innovation, the very novelty of which makes historical comparisons difficult. ${ }^{59}$ As IMF-researchers put it:

Since we are dealing with rare events, historical experience may [...] be of limited value. Comparisons with past occurrences may not be useful, since with evolution of the financial system in terms of contracts, institutions, operations, technology, and regulations, the nature of the interactions among financial players and the contagion mechanisms may be quite different. ${ }^{60}$

Looking at deviations from historical averages requires the future to match the past, increasing the risk that supervisors are preparing for yesterday's crisis.

52 White (2008), 310-11.

53 Shin (2013); ESRB (2014c).

54 McPhilemy and Roche (2013), 77.

55 European Parliament and European Council (2010), article 16 (4).

56 ESRB (2015).

57 Ibid. (2017).

$\mathbf{5 8}$ Interview 7.

59 Bronk (2013); Borio and Drehmann (2009).

60 Agur and Sharma (2013), 9. 
Moreover, the non-linearity inherent to complex systems means that it is hard to know when trends have become unsustainable: "threshold effects severely complicate efforts to quantify the risk of a systemic crisis, and make it particularly difficult for a warning system to be 'early,' and not just begin to flash red when it is too late [...]."61 As an EU-policymaker admits, "when you try to do countercyclical policy you must know and identify the cycle [..]. And this is something which is inherently difficult."62

So in contrast to the risk dashboard, the ESRB does not publish the heat maps. An EU-policymaker explains why:

In the past couple of years, Europe has been exposed to tremendous risks, [but] many of the indicators we had [...] started to signal green exactly when we were most preoccupied. Which basically means that they are not usable. They give false positives. And the reason for that is that they have been calibrated to past crises [...]. They do not signal new sources of concern. So the heat map is not sufficiently adequate for public communication. [...] It would simply create the impression that you do not have a way to catch reality. ${ }^{63}$

Notwithstanding the ESRB's progress in developing ways to signal systemic risks, there is an inherent indeterminacy in its early warning systems. The same EU-policymaker laments: "the reality is that we do not yet have a good system for that."64

\section{Calibrating countercyclical instruments}

In addition to designing early warning systems, policymakers have also attempted to calibrate countercyclical instruments with reference to systemic risk indicators. They agreed that a (more or less) rules-based calibration of instruments would be preferable over an open-ended policy relying on supervisory discretion. ${ }^{65}$ Rules would act as an effective pre-commitment device: during a boom, supervisors would not need to justify increasing rule-stringency, avoiding opposition from optimistic market participants or politicians: "There is a strong incentive to wait and see. [...] Supervisors will have a hard time pursuing countercyclical policies when everything goes well, because then there is just much more evidence that there are no risks than that they are there." 66 The message was clear: "[in] principle,

\footnotetext{
61 Ibid., 8.

62 Interview 9.

63 Interview 7.

64 Ibid.

65 BIS (2008); Borio and Drehmann (2009); Brunnermeier et al. (2009); IMF (2009).

66 Interview 2.
} 
rules are preferable." ${ }^{\prime 67}$ The Committee of European Banking Supervisors (CEBS) went even further, stating that "countercyclical approaches should be based on automatic rules." 68 Yet, if we look at bank capital and liquidity requirements, no such automaticity has been developed. Instead, supervisors have much discretion in how to calibrate the instruments.

The CCB, part of Basel III, is arguably the most developed tool. If systemic risks build up, banks should maintain an extra capital (equity) buffer on top of normal requirements. Rather than just delegate systemic risk identification to national supervisors, the Basel Committee set out to design a calibration method to ensure some discipline. ${ }^{69}$ Given the limitations of market price and balance sheet indicators, it saw indicators based on deviations from historical trends as most promising. Examining a range of candidates, a BIS-discussion paper identified the so-called "credit-to-GDP gap" as the best leading indicator for financial distress. This indicator measures the deviation from the trend of the ratio of "credit to the private sector" to "a country's GDP." A substantial deviation would signal abnormal credit growth, indicating future troubles. ${ }^{70}$

Although promising, BIS-analysts remained cautious about the credit-to-GDP gap indicator: "our analysis indicates [...] that any fully rule-based mechanism may not be possible at this stage. As a result, some degree of judgement, both for the build-up as well as the release phase, seems inevitable."71 The problem is, as an EU-policymaker put it, that "if you take multiple indicators it becomes terribly difficult to calibrate the instrument, but one indicator fails to incorporate everything you want to know."72 A central bank official emphasized that "the credit-to-GDP gap works well for crises in the past, but it might very well fail for future crises."73 Other experts argued that the indicator's reference to GDP might make it operate procyclically, as a country experiencing economic growth would see its credit-toGDP gap fall, and vice versa. ${ }^{74}$

While the BCBS ultimately embraced this indicator, it was vague on the indicator's intended role, stating that Basel III "does not require that the specific, internationally-consistent credit/GDP guide play a dominant role," while simultaneously stressing that this "does not imply that it should it be totally ignored."75

67 FSF (2009), 11.

68 CEBS (2009), 2.

69 Interview 2.

70 Drehmann et al. (2010).

71 Ibid., 27.

72 Interview 9.

73 Interview 2.

74 Repullo and Saurina (2011).

75 BCBS (2010), 4. 
The EU's adoption of the CCB copies this ambiguity. At an early stage, the EC had indicated that a strict rules-based regime would "require a high degree of confidence that the variables used would under all circumstances perform as intended and would not send false signals," stating that "[this] level of confidence will not be possible."76 CRD IV, thus, requires authorities to use the indicator as "a common starting point for decisions," while emphasizing that it "should not give rise to an automatic buffer setting or bind the designated authority." 77 The ESRB even recommended that member states "should take into account a range of information when assessing the level of system-wide risk and set the buffer rate accordingly."78

Supervisors, thus, have much discretion in the CCB's calibration. According to an EU policy official, this is an inevitable consequence of the measurement problem: "How do you measure systemic risk? Nobody knows. There is not a unique measure, so I think that discretion is not going to be overcome for the next one-hundred years, or so."79 Relying on past trends to guide future actions will inevitably be problematic, according to the same EU policy official:

True, there is this credit-to-GDP gap that by law you have to look at. But there are many reasons why this indicator might not give you precise indications. [...] If you look at it in different countries, the indicator is minus $25 \%$ and it will take fifty years before it comes back. So maybe you had a trend that was not really sustainable for many years before. So it is all biased. $^{80}$

If blindly followed, the bias inherent in using a historical trend-indicator would prevent the countercyclical buffer from being activated, as it may have been distorted by pre-crisis credit growth. Supervisors are therefore looking at a wide range of indicators to guide decisions on the CCB's activation. The UK Financial Policy Committee, for example, lists eighteen "core indicators," without specifying how it would ultimately decide on activating the CCB. ${ }^{81}$

The search for risk indicators proved even more difficult for systemic liquidity risk. ${ }^{82}$ Liquidity is where market reflexivity is arguably the most problematic: "liquidity [...] depends on confidence, i.e. the ability of depositors, institutions, and market participants to take risks on each other." 83 This confidence can disappear rapidly: "changes in expectations and the resulting adjustments in risk

76 European Commission (2010), 55.

77 European Parliament and European Council (2013), recital 82.

78 ESRB (2014b), recital 7.

79 Interview 6.

80 Ibid.

81 Financial Policy Committee (2016).

82 Interview 3; Interview 5.

83 Banque de France (2008). 
appetites can transform market liquidity, and alter the path and volatility of asset prices." ${ }^{84}$ As a banking regulator admits, finding indicators for systemic liquidity risk is hard: "liquidity can disappear quite suddenly. Even a well-capitalized bank can suddenly experience liquidity stress." ${ }^{85}$ As liquidity is ultimately endogenous to financial system functioning, the search for a limited set of suitable indicators proved futile.

In fact, the Basel III liquidity rules - the Liquidity Coverage Ratio (LCR) and the Net Stable Funding Ratio (NSFR), finalized in 2013 and 2015, respectively-do not contain explicit countercyclical elements. ${ }^{86}$ According to a banking regulator, the LCR has a modest macroprudential dimension: "authorities have very clearly gone out of their way to emphasize that people can dip into their liquidity buffers when they need to. So that is a macroprudential element in the calibration of the tool. But that is the only one." 87 But the rules are vague on when the LCR can be breached. Another banking regulator explains: "when we were developing the LCR [...] we did talk about having a rules-based approach. So supervisors would have some measures of market liquidity indicators and they would use those to judge when liquidity is drying up in markets." ${ }^{88}$ But the BCBS abandoned this route: "nowhere in the final document [on Market-Based Indicators of Liquidity] does it say 'supervisors need to use these.'" 89

Again, the problem was finding appropriate indicators. The key problem, according to the same banking regulator, is the "idea of predicting market liquidities. We can't perfectly predict it and if regulators are extremely prescriptive, you are constraining authorities in a time of stress from doing something. Because that stress doesn't show up in a single indicator or even a set of indicators. [...] You can't fit every crisis to a model, and you can't fit a model to every crisis." ${ }^{90}$ As a result, the BCBS is vague on this issue, merely stating that "during periods of stress, it would be entirely appropriate for banks to use their stock of [high quality liquid assets], thereby falling below the minimum." 91

While EU law, in principle, allows macroprudential authorities to use liquidity requirements in a countercyclical manner, progress on identifying risk indicators to calibrate them has so far been limited. The ECB has recently listed twenty different indicators to assess systemic liquidity risk, thereby exposing the

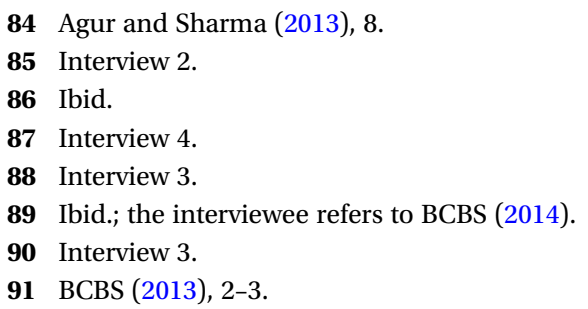


measurement problem. ${ }^{92} \mathrm{~A}$ banking regulator considers it unlikely that liquidity requirements will eventually contain a tightly calibrated countercyclical add-on, calling it "extremely difficult to calibrate such a tool." 93 Similarly, a leading member of the ECB's taskforce on systemic liquidity, says that the "activation [of instruments is] challenging given lack of reliable indicators." ${ }^{94}$ Limits to systemic risk measurement, thus, severely hamper the calibration of countercyclical instruments, contributing to the open-endedness of macroprudential policies.

\section{The mitigation problem in practice}

\section{Mitigating systemic risks}

A second, crucial issue for countercyclical policies is how supervisors should respond when they flag the buildup of systemic risks. But both rule-based and discretionary interventions may have significant unintended consequences. The upside of a rule-based approach is that it acts as a pre-commitment device and creates clarity among market participants about under what circumstances rules become more or less stringent. However, the problems of rule-based instruments go beyond the measurement issues identified above: as the IMF, FSB, and BIS warn, attempts to "target predefined ranges of indicators can lead risks to shift in unintended ways."95 The ESRB points out a similar problem, arguing that "the behaviour and predictive power of the indicators may change once they are used for the (de)activation of policy instruments."96

Such warnings are related to "Goodhart's Law": "any observed regularity will tend to collapse once pressure is placed upon it for control purposes." ${ }^{7}$ According to a banking regulator, this is serious risk: "For supervisors it would be great to finally have indicators that allow you to measure systemic risk and predict financial instability, but in practice this is nearly impossible. The moment you would make a particular systemic risk indicator central to your policy framework, market participants' reactions to this choice will undo its relevance over time." 98 In short,

\footnotetext{
92 ECB (2018), 35.

93 Interview 1.

94 Wedow (2018), 29.

95 IMF, FSB, and BIS (2016), 13-4.

96 ESRB (2014c), 127.

97 Goodhart (1984), 96.

98 Interview 1.
} 
policymakers fear that a hardwired countercyclical approach could, over time, become meaningless, due to market participants' endogenous response to the rules.

The alternative-discretionary interventions-comes with problems of its own: unpredictable interventions could give rise to serious unintended consequences. The Committee on the Global Financial System (CGFS) warns that "the risk of triggering undesired behavioural consequences may argue against immediate actions," as "markets might become unsettled if authorities choose an action that could be wrongly interpreted as reflecting that the macroprudential authority has knowledge of imminent risks." 99 Similarly, the ESRB stresses that an "important unintended effect is the potential feedback effect that the announcement of a buffer release might have on the financial system. The announcement itself may be considered as tantamount to an official declaration of a systemic event." ${ }^{100}$ While the ESRB suggests to resolve this by making "the release decision a quasi-automatic process based on the triggering of publicly observed market indicators,"101 this brings us back to the problems mentioned above.

Another problem for which policymakers have been unable to find a solution is how to deal with a downturn. During a crisis, the "micro/macro"-paradox operates in full force, as panic at the individual level rapidly destabilizes the system, making everyone worse off. ${ }^{102}$ Microprudential supervision may add to this problem. As a banking regulator recalls, "the supervisor's first reaction after Lehman Brothers was to tell banks 'keep all the liquidity you have.' And the people in the market said 'this is crazy, because then the market dies out and everything will crash.'"103 Yet the alternative strategy_letting individual firms' financial positions deteriorate in the hope that markets will recover-is problematic too. If regulatory leniency ultimately leads to bankruptcies, this may add to the problems rather than limit them. There is no consensus on how to deal with this problem: "We still have to see. [...] Because I think the main conflict is not in a phase like we are in now. The main potential conflict [between micro and macro perspectives] will come in a downturn, in a serious downturn, in a serious financial crisis. Then the two perspectives will really, really need to confront each other a lot. [...] We don't have the proof of the real test." ${ }^{104}$ As there is no obvious countercyclical strategy, policymakers have effectively deferred the issue.

\footnotetext{
99 CGFS (2016).

100 ESRB (2014c), 110.

101 Ibid.

102 Baker (2013b).

103 Interview 6.

104 Ibid.
} 


\section{Limiting procyclicality}

Policymakers have also been confronted with the mitigation problem on another key macroprudential issue: financial firms' risk assessment practices. Risk models not merely measure but shape risks, and can do so in destabilizing ways. Worse still, regulatory prescriptiveness might contribute to herd behavior, adding to the problem rather than solving it. I will discuss how these obstacles have hampered reform in two areas specifically labelled as key reform priorities: capital requirements' procyclical effects and loan-loss provisioning. ${ }^{105}$

Critics pointed at banks' risk models as a key source of procyclicality. ${ }^{106}$ These models' short time horizon and reliance on market-based data contributed to excessive optimism in the boom and panic in the bust. Observers argued that regulatory reliance on firms' risk models had reinforced this dynamic, and pointed specifically at the Internal Ratings Based (IRB)-approach of the Basel II Accord (2004). As Basel II did not prescribe one particular risk modelling philosophy, most banks leaned towards PIT models, as these were easier to design than TTC models and better fitted banks' internal operations. ${ }^{107}$ The crisis challenged this approach. As policymakers had introduced a so-called "use test" in Basel IIrequiring IRB banks to use the same risk estimates for regulatory and internal risk management purposes ${ }^{108}$-a solution seemed obvious: policymakers could make IRB eligibility contingent upon banks' use of non-procyclical risk models.

But policymakers have been hesitant to harmonize banks' risk assessment practices. The obvious solution would be to prescribe a wholesale shift towards TTC models, but regulators feared this would eliminate the advantages of PIT models, which are more sensitive to changes in economic circumstances. In particular, the TTC approach understates risks in periods with rising defaults, implying that firms are unprepared when problems hit them. ${ }^{109}$ Moreover, they worried about the potential detrimental effects of harmonization. ${ }^{110}$ As a banking regulator has recently framed the issue, "model variability reduces the risk of herding behaviour, which would arise if every bank were to use the same standardised approach." 111 While private sector discretion has clear downsides, publicly

\footnotetext{
105 BCBS (2009a), 66-72.

106 Di Noia et al. (2009); Warwick Commission (2009).

107 FSA (2009a).

108 BCBS (2006).

109 Repullo et al. (2009).

110 Interview 8; Interview 11.

111 Dombret (2017), 3.
} 
prescribed risk models might worsen the problem. ${ }^{112}$ Policymakers, thus, see no way out of the current hybrid approach, in which PIT models incorporate TTC elements, and where banks still have a significant amount of discretion. ${ }^{113}$

While there have been more significant reforms of loan-loss provisioning rules, the underlying regulatory dilemma continues to haunt policymakers. Under the pre-crisis "incurred loss approach," banks generally had to wait for losses to materialize before they could make a provision. Banking regulators blamed this approach for inducing procyclicality, although they had to admit that banks themselves had also failed to make prudent provisioning decisions. They argued for a more forward-looking approach. ${ }^{114}$

Europe's standard setter, the International Accounting Standards Board (IASB), appeared susceptible to regulators' wishes. It proposed an "expected loss approach," giving firms more freedom to use their risk models to assess future problems. ${ }^{115}$ But the devil was in the details. Fearing discretion would allow firms to "cook the books," the IASB favored a PIT approach, as this would be easier to verify than the more subjective TTC approach. Banking regulators, in contrast, feared for worse forms of procyclicality: "if [provisions are] calculated by reference to current market expectations of future losses, there is a danger that the new approach could actually be more procyclical than the past." ${ }^{116}$ But they also recognized that firm discretion could have undesirable consequences: "[If] calculated by reference to judgements about future possible losses [...] investors might have concerns whether these [...] are based on fact [...]."117

The final version of the expected loss approach—issued in 2014-was a compromise solution, with the IASB keeping the PIT approach, while incorporating TTC elements. ${ }^{118}$ Although stakeholders, in principle, support this approach, IFRS 9 has nonetheless become a cause for much concern. While accountants and investors fear the increased discretionary space, many EU banks see a different problem: they expect the standard to substantially increase required provisions. ${ }^{119}$ Given recent bad economic circumstances, the PIT estimates are quite pessimistic. ${ }^{120}$ As provisions are deducted from income (also affecting capital figures), banking representatives blame the standard for procyclicality. And as any

\footnotetext{
112 Stellinga and Mügge (2017).

113 EBA (2015).

114 FSF (2009); BCBS (2009b).

115 IASB (2009).

116 Turner (2010), 3.

117 Ibid., 3-4.

118 Novotny-Farkas (2015).

119 Ibid.; Interview 10.

120 Interview 11.
} 
mismatch in banks' actual and required provisions are (up to a certain level) deducted from regulatory capital, a failure to substantially increase provisions would also deal a significant blow to banks' capital adequacy figures. ${ }^{121} \mathrm{EU}$ banks say they are stuck between a rock and a hard place.

EU policymakers dislike the idea of banks' profitability and capital adequacy ratios taking another hit: "Banking supervisors and the European Commission are getting anxious, asking themselves: 'are we going from too little too late to too much too early?'"122 The EC has recently suggested a transitional arrangement of up to five years after IFRS 9 enters into force (which happened in January 2018), to ensure a limited impact on capital figures. ${ }^{123}$ Yet giving banks breathing space now might merely make future problems worse. The aggregate level of EU banks' provisions is already deemed insufficient to address the non-performing loans problem. ${ }^{124}$ Are regulators confident that better times are around the corner, so that they can be lenient for now? There is no way to tell. It might just as well prolong the current malaise far into the future. Even with the new macroprudential philosophy, policymakers face an intractable dilemma.

\section{Conclusion}

Policymakers' embrace of an open-ended macroprudential policy framework ultimately stems from their appreciation of inherent measurement and mitigation problems. As the financial system is reflexive, adaptive, and complex, there are limits to supervisors' ability to "read" the cycle. Furthermore, as macroprudential policy itself becomes "endogenous to financial markets," countercyclical interventions may have systemically significant unintended consequences. No policy approach promises to mitigate systemic risks under all circumstances, stimulating policymakers to defer the issue to supervisors. Similarly, mitigating the destabilizing effects of firms' risk approaches is easier said than done: a hands-on policy risks inducing herding behavior by steering all firms in the same direction. A hybrid approach, combining regulatory prescriptiveness on some aspects of risk assessment, with private sector discretion on others, seems the best policymakers can do. Policymakers have, thus, delegated responsibility for systemic risk mitigation to supervisors and firms, without specifying how they should do this.

121 Contiguglia (2016); Marlin (2017).

122 Interview 10.

123 EC (2016b), 264-5; BCBS (2016).

124 IMF (2015). 
Macroprudential policy's indeterminacy will likely be a permanent feature, instead of being resolved over time with data and model improvements. This is not to say that the "macroprudential turn" has been a futile exercise. The institutionalization of a systemic risk perspective in the supervisory architecture has been a significant improvement. And macroprudential instruments, such as loan-tovalue and leverage ratio limits, can certainly contribute to financial stability, even if they will not prevent all problems. ${ }^{125}$

On the other hand, it is unlikely that macroprudential policies will, on their own, prevent meltdowns like the 2007-9 crisis. The risk of overstating macroprudential policy's significance is that it legitimates the status quo in other policy domains. According to a banking regulator, "macroprudential overlays have a greater probability of success if they are based on a very, very strong microprudential framework." ${ }^{26}$ But observers warn that politicians' trust in macroprudential policies unwittingly legitimates an overly weak baseline microprudential policy. ${ }^{127}$ Monetary policy is another example: "some monetary policy authorities think that macroprudential policy is enough to deal with financial stability. I think it can help and it is definitely part of the solution, but it cannot solve the problem." ${ }^{128}$ In short, expecting too much from macroprudential policy might unwittingly pre-empt reforms in other key policy areas.

All this underlines the importance of policy coherence. Macroprudential supervisors need help from policymakers in other domains. This includes, but is not limited to, microprudential and monetary policy. Fighting our debt-addiction would go a long way in protecting society from unbearable costs when financial markets inevitably turn. ${ }^{129}$ This suggests extending stability considerations beyond financial regulation to include socioeconomic policies. Introducing loan-to-value ratios may be of limited value if tax regimes, pension frameworks, and housing market policies simultaneously stimulate excessive private sector indebtedness. To mitigate systemic risks, other policy domains will need to incorporate financial stability considerations.

Another important issue that risks being eclipsed is financial sector heterogeneity. ${ }^{130}$ The crisis showed that risk diversification at the firm level can go hand in hand with financial monocultures and herd behavior. ${ }^{131}$ Similarities in major

\footnotetext{
125 Agur and Sharma (2013).

126 Interview 4.

127 Barwell (2014); Daníelsson (2016).

128 Interview 4.

129 Turner (2015); OECD (2015).

130 Butzbach (2016).

131 Haldane (2009).
} 
banks' business models reinforces the procyclicality problem: in boom times, banks taking higher risks gain market share, forcing direct competitors to go along. ${ }^{132}$ Striving for more heterogeneity, with financial institutions specializing more in different activities and with more variance in financial regulations that apply to these institutions, would reduce our dependence on the ability of supervisors to timely identify and mitigate systemic risks. ${ }^{133}$

\section{Interviews}

Interview 1: Banking regulator (two respondents) - National authority; 16 March 2016

Interview 2: Banking regulator (two respondents) - National authority; 3 November 2016

Interview 3: Banking regulator - Global policy institution; 22 November 2016

Interview 4: Banking regulator - Global policy institution; 24 November 2016

Interview 5: Financial market regulator - Global policy institution; 24 November 2016

Interview 6: Banking regulator - European policy institution; 30 November 2016

Interview 7: Banking regulator - European policy institution; 1 December 2016

Interview 8: Banking sector representative (two respondents) - National level; 5 December 2016

Interview 9: Banking regulator (two respondents) - European policy institution; 7 December 2016

Interview 10: Banking regulator - European policy institution; 7 December 2016 Interview 11: Banking sector representative (two respondents) - European level; 8 December 2016

\section{References}

Admati, A. 2016. "The missed opportunity and challenge of capital regulation." National Institute Economic Review 235 (1): 4-14.

Admati, A., and M. Hellwig. 2013. The Bankers' New Clothes. Princeton, N): Princeton University Press.

Adrian, T., and H.Y. Shin. 2009. "Liquidity and leverage." FED of New York Staff report, no. 328. FED of New York.

132 Crockett (2008).

133 Goodhart and Wagner (2012). 
Agur, I., and S. Sharma. 2013. "Rules, Discretion, and Macro-Prudential Policy.” IMF Working Paper, 13/65. Washington, D.C.: IMF.

Baker, A. 2013a. "The gradual transformation? The incremental dynamics of macroprudential regulation." Regulation \& Governance 7 (4): 417-34.

Baker, A. 2013b. "The New Political Economy of the Macroprudential Ideational Shift." New Political Economy 18 (1): 112-39.

Baker, A. 2018. "Macroprudential regimes and the politics of social purpose." Review of International Political Economy 25 (3): 293-316.

Banque de France. 2008. Financial Stability Review no. 11. Special Issue on Liquidity, February 2008. Paris: Banque de France.

Barwell, R. 2014. "The macroprudential voyage of discovery: no map, no specific destination in mind... no problem?” 196-217. In Putting Macroprudential Policy to Work, edited by A. Houben, R. Nijskens, and M. Teunissen. Amsterdam: DNB.

BCBS. 2006. The IRB Use Test: Background and Implementation. Basel: BIS.

BCBS. 2009a. Consultative Document. Strengthening the resilience of the banking sector. Basel: BIS.

BCBS. 2009b. Guiding Principles for the replacement of IAS 39. Basel: BIS.

BCBS. 2010. Guidance for national authorities operating the countercyclical capital buffer. Basel: BIS.

BCBS. 2013. Basel III: The Liquidity Coverage Ratio and liquidity risk monitoring tools. Basel: BIS.

BCBS. 2014. Guidance for Supervisors on Market-Based Indicators of Liquidity. Basel: BIS.

BCBS. 2016. Regulatory treatment of accounting provisions - interim approach and transitional arrangements. Basel: BIS.

BIS. 2008. Addressing financial system procyclicality: a possible framework. Note for the FSF Working Group on Market and Institutional Resilience. Basel: BIS.

Borio, C. 2003. "Towards a macroprudential framework for financial supervision and regulation?" BIS Working Papers, no. 128. Basel: BIS.

Borio, C. 2009. "Implementing the macroprudential approach to financial regulation and supervision." Banque de France Financial Stability Review, no. 13. Paris: Banque de France.

Borio, C. 2011. "Rediscovering the macroeconomic roots of financial stability policy: journey, challenges and a way forward." BIS Working Papers, no. 354. Basel: BIS.

Borio, C., and M. Drehmann 2009. "Towards an operational framework for financial stability: "fuzzy" measurement and its consequences." BIS Working Papers, no. 264. Basel: BIS.

Bronk, R. 2013. "Reflexivity unpacked: performativity, uncertainty and analytical monocultures." Journal of Economic methodology 20 (4): 343-49.

Brunnermeier, M., A. Crocket, C. Goodhart, A.D. Persaud, and H. Shin. 2009. The Fundamental Principles of Financial Regulation. Geneva: International Center for Monetary and Banking Studies.

Butzbach, 0. 2016. "Systemic risk, macro-prudential regulation and organizational diversity in banking." Policy and Society 35 (3): 239-51.

CEBS. 2009. Position paper on a countercyclical capital buffer. London: CEBS.

CGFS. 2012. "Operationalising the selection and application of macroprudential instruments." CGFS Papers, no. 48. Basel: BIS.

CGFS. 2016. "Experiences with the ex ante appraisal of macro-prudential instruments." CGFS Papers, no. 56. Basel: BIS.

Claessens, S., S. Gosh, and R. Mihet. 2014. "Macro-Prudential Policies to Mitigate Financial System Vulnerabilities.” IMF Working Paper, 14/155. Washington, D.C.: IMF. 
Contiguglia, C. 2016. “IFRS 9 packs bigger punch than Basel changes, say bankers.” Risk.Net, 15 June 2016.

Crockett, A. 2000. "Marrying the micro- and macro-prudential dimensions of financial stability." Remarks at the Eleventh International Conference of Banking Supervisors, Basel, 20-21 September 2000.

Crockett, A. 2008. "Market liquidity and financial stability." Banque de France Financial Stability Review. Paris: Banque de France, 13-8.

Daníelsson, J. 2016. "Systemic risk and financial regulations: What is the link?" Presentation given for European Commission (Economic Analysis), Internal Market and Services DG Conference, 27 February 2014. European Commission, Brussels.

Daníelsson, J., and H.S. Shin. 2003. "Endogenous risk." In Modern risk management: A history, edited by P. Field. London: Risk Books, 297-316.

Daníelsson, J., P. Embrechts, C. Goodhart, C. Keating, F. Muennich, O. Renault, and H.S. Shin. 2001. "An academic response to Basel II." LSE Financial Markets Group Special Papers Series, no. 130. London: London School of Economics.

Di Noia, C., S. Micossi, J. Carmassi, and F. Peirce. 2009. Keep it simple. Policy responses to the financial crisis. Brussels: CEPS.

Domanski, D., and T. Ng. 2011. "Getting effective macroprudential policy on the road: eight propositions.” In: BIS (ed.) Macroprudential regulation and policy, BIS Papers, no 60.

Dombret, A. 2017. "To count or not to count - the future of internal models in banking regulation." Available at: https://www.bis.org/review/r171211a.pdf (accessed on 22 March 2019).

Drehmann, M., C. Borio, L. Gambacorta, G. Jiménez, and C. Trucharte. 2010. “Countercyclical capital buffers: exploring options.” BIS Working Papers, no. 317. Basel: BCBS.

EBA. 2015. The EBA's regulatory review of the IRB approach. Conclusions from the consultation on the Discussion Paper on the "Future of the IRB approach." London: EBA.

ECB. 2015a. ECB comments on EFRAG draft endorsement advice on the adoption of IFRS 9 Financial Instruments. Frankfurt: ECB.

ECB. 2015b. ECB response to the European Commission's consultation on the review of the European Market Infrastructure Regulation (EMIR). Frankfurt: ECB.

ECB. 2018. Systemic liquidity concept, measurement and macroprudential instruments. Frankfurt: ECB.

ESCB Heads of Research. 2014. Report on the Macro-Prudential Research Network (MARS). Frankfurt: ECB.

ESRB. 2014a. ESRB response to the call for advice by the European Commission on macro-prudential rules in the CRD/CRR. Frankfurt: ESRB.

ESRB. 2014b. Recommendation on guidance for setting countercyclical buffer rates. ESRB/2014/1, Official Journal of the European Union.

ESRB. 2014c. The ESRB Handbook on Operationalising Macro-prudential Policy in the Banking Sector. Frankfurt: ESRB.

ESRB. 2015. Annual Report 2014. Frankfurt: ESRB.

ESRB. 2016a. A review of Macroprudential Policy in the EU in 2015. Frankfurt: ESRB.

ESRB. 2017. Annual Report 2016. Frankfurt: ESRB.

ESRB. 2018. ESRB risk dashboard. November 2018. Frankfurt: ESRB.

European Commission. 2010. Possible further changes to the Capital Requirements Directive. Brussels: EC.

European Commission. 2016a. Consultation Document. Review of the EU Macro-Prudential Policy Framework. Brussels: EC. 
European Commission. 2016b. Proposal for a Regulation of the European Parliament and of the Council amending Regulation (EU) No. 575/2013. Brussels: EC.

European Parliament and European Council. 2010. Regulation (EU) No 1092/2010 of 24 November 2010 on European Union macro-prudential oversight of the financial system and establishing a European Systemic Risk Board. Brussels: EUP and European Council.

European Parliament and European Council. 2013. Directive 2013/36/EU of 26 June 2013 on access to the activity of credit institutions and the prudential supervision of credit institutions and investment firms. Brussels: EUP and European Council.

Financial Policy Committee. 2016. The Financial Policy Committee's approach to setting the countercyclical capital buffer. London: Bank of England.

FSA. 2009a. A regulatory Response to the Global Banking Crisis, Discussion paper 2009/02. London: FSA.

FSA. 2009b. The Turner Review. A regulatory response to the global banking crisis. London: FSA.

FSB, IMF, and BIS. 2011. Macroprudential Policy Tools and Frameworks. Progress Report to the G20. Basel: FSB.

FSF. 2009. Report of the Financial Stability Forum on Addressing Procyclicality in the Financial System. Basel: FSF.

FSF-BCBS. 2009. Reducing procyclicality arising from the bank capital framework. Basel: BIS.

FSF-CGFS. 2009. The role of valuation and leverage in procyclicality. Basel: FSF.

Goodhart, C. 1984. Monetary theory and practice. The UK experience. London: Macmillan Press.

Goodhart, C., and W. Wagner. 2012. "Regulators should encourage more diversity in the financial system." VOXEU. Available at: https://voxeu.org/article/regulators-should-encourage-morediversity-financial-system (accessed on 21 March 2019).

Goodhart, L.M. 2015. "Brave New World? Macro-prudential policy and the new political economy of the federal reserve." Review of International Political Economy 22 (2): 280-310.

Haldane, A. 2009. Rethinking the Financial Network. Speech delivered at the Financial Student Association, Amsterdam, 28 April. London: Bank of England. Available at: https://www.bis. org/review/r090505e.pdf (accessed on 19 June 2018).

Haldane, A. 2012. Financial arms races. Speech by Andrew G. Haldane, executive director, Financial Stability, Bank of England, at the Institute for New Economic Thinking, Berlin, 14 April 2012. London: Bank of England.

Helleiner, E. 2014. The Status Quo Crisis. Global Financial Governance After the 2008 Financial Meltdown. Oxford: Oxford University Press.

Hellwig, M. 2014. "Systemic risk and macroprudential policy." In Putting Macroprudential Policy to Work, edited by A. Houben, R. Nijskens, and M. Teunissen, 42-77. Amsterdam: De Nederlandche Bank.

High-Level Group on Financial Supervision in the EU. 2009. The de Larosière Group Report. Brussels: European Commission.

IASB. 2009. IASB Exposure Draft “Financial Instruments: Amortised Cost and Impairment." London: IASB.

IMF. 2009. Lessons of the Financial Crisis for Future Regulation of Financial Institutions and Markets and for Liquidity Management. Washington, D.C.: IMF.

IMF. 2015. A Strategy for Resolving Europe's Problem Loans. Washington, D.C.: IMF.

IMF, FSB, and BIS. 2016. Elements of Effective Macroprudential Policies. Washington, D.C.: IMF.

Konings, M. 2016. "Governing the system: Risk, finance, and neoliberal reason." European Journal of International Relations 22 (2): 268-88. 
Lockwood, E. 2015. "Predicting the unpredictable: Value-at-Risk, performativity, and the politics of financial uncertainty." Review of International Political Economy 22 (4): 719-56.

Lombardi, D., and M. Moschella. 2017. "The symbolic politics of delegation: Macroprudential policy and independent regulatory authorities." New Political Economy 22 (1): 92-108.

Lothian, T. 2012. "Beyond Macroprudential Regulation: Three Ways of Thinking about Financial Crisis, Regulation and Reform." Global Policy 3 (4): 410-20.

MacKenzie, D. 2006. An engine, not a camera: How financial models shape markets. Cambridge, MA: MIT Press.

Mackintosh, S.P.M. 2014. “Crises and Paradigm Shift.” The Political Quarterly 85 (4): 406-12.

Marlin, S. 2017. "Basel set to decide on capital relief for accounting changes." Risk.net, 16 January 2017.

May, R. M., S. A. Levin, and G. Sugihara. 2008. “Complex systems: Ecology for bankers.” Nature 451 (7181): 893.

McPhilemy, S. 2016. “Integrating macro-prudential policy: central banks as the 'third force' in EU financial reform." West European Politics 39 (3): 526-44.

McPhilemy, S., and J. Roche. 2013. Review of the New European System of Financial Supervision. Part 2: The work of the European Systemic Risk Board - The ESFS's macro-prudential pillar. Brussels: European Parliament.

Minsky, H.P. 2008 [1986]. Stabilizing and Unstable Economy. New York: McGrawHill.

Mügge, D.K., and B. Stellinga. 2015. "The unstable core of global finance: Contingent valuation and governance of international accounting standards." Regulation and Governance 9 (1): 47-62.

Novotny-Farkas, Z. 2015. The Significance of IFRS 9 for Financial Stability and Supervisory Rules. Study for European Parliament - Policy Department A: Economic and Scientific Policy. Brussels: European Parliament.

OECD. 2015. How to restore a healthy financial sector that supports long-lasting, inclusive growth? Paris: OECD.

Repullo, R., and Saurina, C. 2011. "The Countercyclical Capital Buffer of Basel III: A Critical Assessment.” Available at: ftp://ftp.cemfi.es/pdf/papers/repullo/Repullo-Saurina\%20Final \%20R.pdf (accessed on 21 March 2019).

Repullo, R., J. Saurina, and C. Trucharte. 2009. Mitigating the Procyclicality of Basel II. CEMFI Working Paper No. 0903.

Shin, H.S. 2013. "Procyclicality and the Search for Early Warning Indicators." IMF Working Papers, $\mathrm{WP} / 13 / 258$.

Soros, G. 2008. The New Paradigm for Financial Markets: The Credit Crisis of 2008 and What It Means. New York: PublicAffairs.

Stellinga, B., and D.K. Mügge. 2017. "The regulator's conundrum. How market reflexivity limits fundamental financial reform.” Review of International Political Economy 24 (3): 393-423.

Thiemann, M. 2018. "Is resilience enough? The macroprudential reform agenda and the lack of smoothing of the cycle." Public Administration. https://doi.org/10.1111/padm.12551.

Thiemann, M., M. Birk, and J. Friedrich. 2018. "Much ado about nothing? Macro-prudential ideas and the post-crisis regulation of shadow banking." KZfSS Kölner Zeitschrift für Soziologie und Sozialpsychologie 70 (1): 259.

Turner, A. 2010. "Banks are different: should accounting reflect that fact?" Speech given at the Institute of Chartered Accountants in England and Wales. London, 21 January 2010.

Turner, A. 2015. Between debt and the devil. Princeton, NJ: Princeton University Press. 
Underhill, G.R.D. 2015. "The emerging post-crisis financial architecture: The path-dependency of ideational adverse selection." The British Journal of Politics and International Relations 17 (3): 461-93.

Warwick Commission. 2009. In Praise of Unlevel Playing Fields. Coventry, United Kingdom: The University of Warwick.

Wedow, M. 2018. Macroprudential Policy Implementation in Europe. Session 4: Liquidity Instruments and Systemic Liquidity. Frankfurt: ESRB and ECB.

White, W.R. 2004. "Making macroprudential concerns operational." Speech at a Financial Stability Symposium at the Netherlands Bank, Amsterdam, 25-26 October.

White, W.R. 2008. "Past financial crises, the current financial turmoil, and the need for a new macrofinancial stability framework." Available at: https://www.bis.org/speeches/sp080326. htm (accessed on 22 March 2019). 